\title{
The Determination of Reward and Punishment Using WASPAS Method
}

\author{
Mira Afriana UTAMI ${ }^{1}$ and Endang Lestari RUSKAN ${ }^{2 *}$
}

\author{
${ }^{I}$ miraafrianautami15@gmail.com, Department of Information System, Computer Science Faculty of Sriwijaya University, \\ Indonesia \\ ${ }^{2}$ endanglestari@unsri.ac.id, Department of Information System, Computer Science Faculty of Sriwijaya University, \\ Indonesia \\ *Corresponding author: endanglestari@unsri.ac.id
}

\begin{abstract}
The Public Works Department of Highways and Spatial Planning of South Sumatra Province is an element of implementing government affairs which is the authority of the provincial government in the field of public works and spatial planning for road and bridge affairs and spatial planning. In maintaining the quality of its employees' performance, the Public Works Department of Highways and Spatial Planning of South Sumatra Province regularly evaluate performance every 6 months. Based on the evaluation result will be determined employee who get reward and punishments. In obtaining more accurate and efficient evaluation results, a decision support system is needed that can help in providing recommendations for employees who get rewards and punishments. In this study, the WASPAS Method will be used because it can provide more accurate results with calculations that are quite simple and easy to implement. Also, this method can reduce mistakes or optimize judgment for the selection of the highest and lowest values.
\end{abstract}

Keywords: decision support system, employee performance, reward, punishment, WASPAS

\section{INTRODUCTION}

The Provision of road and bridge infrastructure is the government's obligation to fulfill the rights of citizens to obtain appropriate public services. In its implementation, the Public Works Department of Highways and Spatial Planning of South Sumatra Province attempts to provide and improve road and bridge infrastructure to realize the performance of road infrastructure that is reliable, quality, efficient, smooth, and safe. To reach the target of work can not be separated from the important role of the human resource's quality that participating in ensuring the sustainability of an agency's activities. Employee performance is needed to increase the productivity and professionalism of the agency. At the Public Works Department of Highways and Spatial Planning of South Sumatra Province, there are 228 employees with different sections or fields.

To maintain the quality of the employee's performance, the Public Works and Spatial Planning of the South Sumatra Province periodically conducts an evaluation every 6 months. As feedback from the performance evaluation, the employee who gets the highest evaluation results will be selected to get a reward in the form of additional benefits, while employees who get performance evaluation results below the performance standard will be given punishment in the form of work discipline. Employee performance will be evaluated based on 7 (seven) criteria, namely service orientation, integrity, commitment, discipline, cooperation, leadership, and work realization. But based on the results of interviews with the secretary, it said that in its implementation there were obstacles to the determination of employees who were rewarded and punished. Given a large number of employees and the process of evaluating employee performance that is quite complicated with many criteria, it causes several errors in recording work evaluation data and the process of calculating the results of work evaluation. A large number of employees evaluated causes the process of managing work evaluation results to take quite a long time, this is certainly considered inefficient. From the explanation of the problem, a decision support system is needed that can assist the process of determining the rewarding and punishment.

In this case, we will use the Weighted Aggregated Sum Product Assessment (WASPAS) which aims to facilitate the decision making a process in accordance with the criteria and assessments conducted by the Public Works Department of Highways and Spatial Planning of South Sumatra Province. The WASPAS method is a unique combination of two well-known multi-criteria decision-making (MCDM) approaches, i.e. weighted sum model (WSM) and weighted product model (WPM) [1]. This method is well known for the simplicity of computational processes and the accuracy of results, and WASPAS has been widely accepted as an efficient decision-making tool [2].

\section{Literature Review}

\section{Study Literature}

To justify the applicability and usefulness of the WASPAS method as an effective decision-making tool. Chakraborty, Zavadskas, and Antucheviciene applied the WASPAS 
method by $Q i=\sum_{j=1}^{n} W j \cdot R i j$ following five illustrative examples for solving some multi-criteria in manufacturing election. The result is the robustness of the WASPAS method is proved which will help in its widespread application as an efficient MCDM tool. As it is based on mathematical simplicity and capability to provide more accurate results[3].

Based on research entitled "Decision making about business problems with a far-sighted perspective; the application of the new hybrid MCDM model in a shopping center location" used five alternatives and seven criteria and sub-criteria get the result that WASPAS method is a new methodology with high efficiency and effectiveness in the process of decision making and the authors proposed this method for joining to the process of decision making in this research [4].

\section{DECISION SUPPORT SYSTEM}

Decision support systems (DSS) is the area of the information systems (IS) discipline that is focused on supporting and improving managerial decision-making [5]. Decision Support System (DSS) are computer-based tools that have been adapted to support and aid complex decisionmaking and problem-solving [6]. A well-designed DSS is an interactive software-based system intended to help decisionmakers gather useful information from raw data, documents, personal knowledge, and/or business models to identify and solve problems and make decisions [7]. According to Simon, the process of making a decision is divided into 4 phases, such as [8]:

a. Intelligence phase

At this stage, the decision-maker will conduct an initial investigation by defining the scope of the problem and identifying the information that will be needed in detail.

b. Design phase

The second phase also called the design phase deals with the analysis and formulates alternatives to solve the problem then identifies and evaluates these alternatives.

c. Selection phase

This stage chooses the best solution or alternative among the alternatives.

d. Implementation phase

Implement alternatives or solutions that have been chosen to solve the problem at hand.

\section{REWARD AND PUNISHMENT}

Reward management is one of the strategies used by human resource managers to attract and retain competent employees and also to help them to improve their performance through motivating and complying with employment laws and regulations [9]. The main theme of reward management is to reward employees fairly, equitably and consistently in correlation to the value of these individuals to the organization. A reward system exists to make employees work towards achieving strategic goals through enhancing their productivity and performance levels [10].

\section{WASPAS Method}

WASPAS is a unique combination of well-known weighted sum model (WSM) and weighted product model (WPM) approaches. The mathematical principles behind WASPAS are relatively simple, and it is capable to provide more precise results as compared to traditional WSM and WPM methods. Due to the simplicity of the computational process and accuracy of results, WASPAS has managed to receive significant attention from decision-makers from different walks of life and it is now being widely accepted as an efficient decision-making tool [2]. In its application, the robustness of the WASPAS method is proven to be able to help efficiently as a decision-making tool [3]. The steps in calculating WASPAS method [3][11][12]:

\section{Input Criteria}

The first step is inputting the criteria value in an alternative where the value will be processed and produce a decision.

1. Change the value of each criterion into matrix value

$$
X=\left[\begin{array}{ccc}
x_{11} & x_{1 i} & x_{1 n} \\
x_{j 1} & x_{i j} & x_{j n} \\
x_{m 1} & x_{m i} & x_{m n}
\end{array}\right]
$$

2. Determine the optimal performance value for each criterion $\left(X_{o}\right)$

$$
\mathrm{X}_{\mathrm{o}}=\left\{\begin{aligned}
\operatorname{Max} X i j, j & \in \Pi \max \\
\operatorname{Min} X i j, j & \in \Pi \min
\end{aligned}\right.
$$

Пmax shows the beneficial criteria, i.e. the higher the value the better, and $\prod \min$ shows the cost criteria, i.e. the lower the value the better, $m$ indicates the number of alternatives; $i$ $=0,1, \ldots, \mathrm{m}$, and $\mathrm{n}$ indicate the number of criteria, $\mathrm{j}=0$, $1, \ldots, \mathrm{n}$.

3. Normalization in the WASPAS method At this stage, normalization aims to unite each matrix element so that all elements in the matrix have a uniform value.

$$
\begin{gathered}
\mathrm{R}_{\mathrm{ij}}=\left\{\begin{array}{l}
\frac{x i j}{x \circ j}, j \in \Pi \max \\
\frac{x o j}{m^{2}}, j \in \Pi \min
\end{array}\right. \\
Q i=\prod_{j=1}^{n} \sum(R i j)^{W j}
\end{gathered}
$$

4. Calculate the total relative importance by weighting sum model $\left(\mathrm{Qi}^{1)}\right.$

5. Calculate the total relative importance by weighting product model $\left(Q i^{2}\right)$ 
6. Calculate total relative significance $(Q i)$

A joint generalized criterion of weighted aggregation of additive and multiplicative methods is then proposed as follows :

$$
Q i=0.5\left(Q i^{1}\right)+0.5\left(Q i^{2}\right)
$$

7. Determine the ranking of alternatives based on total relative significance.

\section{RESEARCH METHOD}

According to Simon, the process of making a decision is divided into 4 phases, such as [8]:

1. Intelligence Phase

In this phase, the decision-maker will conduct an initial investigation by defining the scope of the problem and identifying the information that will be needed in detail. The author will interview to find out the procedures for evaluating employee performance that is currently running and also to find out problems or obstacles. After the interview, it is known that an employee performance evaluation will be conducted on 228 employees with feedback that the employee who gets the highest evaluation results will be selected to receive reward in the form of additional benefits, while employees who get the performance evaluation results below this performance standard will be given a punishments in the form of work discipline. Considering a large number of employees and the process of evaluating employee performance that is quite complicated with many criteria causing several errors in recording work evaluation data and the process of calculating the results of work evaluation. Also, the large number of employees evaluated causes the processing of work evaluation results to take a long time so it is considered inefficient. After knowing the problem based on the information obtained, the author can analyze and determine what is needed to develop a new system.

\section{Design Phase}

This phase is the process of modeling the problem that has been defined previously by outlining the decision elements, alternative decision variables, and selected evaluation criteria. The model will be validated by established criteria for evaluating alternatives to the selected decision. The process of determining solutions is the process of designing or developing alternatives, determining decisions, and setting the value and weight given to each alternative that exists.

3. Selection Phase

In this phase, the best solution is chosen between alternatives. This phase includes the process of evaluating and recommending the best solution following the model that has been made. If the solution accepted, then proceed with the implementation phase of the decision solution.

4. Implementation Phase

Implement an alternative or solution that has been chosen to solve the problem encountered. The implementation phase is the final stage of developing a decision support system. This phase is the stage of the system that will be developed using the Weighted Aggregated Sum Product Assessment (WASPAS) method.

\section{RESULTS AND DISCUSSION}

\section{Criteria And Sub-Criteria}

The criteria used in the performance evaluation process consists of seven criteria, namely service orientation, integrity, commitment, discipline, cooperation, leadership, and work realization. Criteria and criteria weights used for evaluating employee performance are the criteria and criteria weights that have been determined by the Department of Public Works and Spatial Planning of South Sumatra Province.

The criteria used are described in Table 1.

Table 1. Criteria and Criteria Weight

\begin{tabular}{|l|l|l|l|}
\hline No. & Criteria (C) & Type & Weight \\
\hline 1. & Service Orientation & Benefit & $5 \%$ \\
\hline 2. & Integrity & Benefit & $20 \%$ \\
\hline 3. & Commitment & Benefit & $15 \%$ \\
\hline 4. & Discipline & Benefit & $7 \%$ \\
\hline 5. & Cooperation & Benefit & $18 \%$ \\
\hline 6. & Leadership & Benefit & $10 \%$ \\
\hline 7. & Work Realization & Benefit & $25 \%$ \\
\hline
\end{tabular}

The sub-criteria used in the Service Orientation Criteria are explained in $\quad Q i=\prod_{j=1}^{n} \sum(R i j)^{W j} \quad$ Table 2. 
Table 2. The Explanation f Service Orientation Criteria

\begin{tabular}{|l|l|l|l|}
\hline No. & Service Orientation & Description & Value \\
\hline 1. & Complete the task as possible with a polite & Very Good & 5 \\
\cline { 3 - 4 } & \multirow{2}{*}{$\begin{array}{l}\text { and satisfying attitude for internal and } \\
\text { external services }\end{array}$} & Good & 4 \\
\cline { 3 - 4 } & & Enough & 3 \\
\cline { 3 - 4 } & Less & 2 \\
\cline { 3 - 4 } & \multirow{2}{*}{2.} & Bad & 1 \\
\hline & & Very Good & 5 \\
\cline { 3 - 4 } & & Good & 4 \\
\cline { 3 - 4 } & & Enough & 3 \\
\cline { 3 - 4 } & & Less & 2 \\
\cline { 3 - 4 } & & Bad & 1 \\
\hline
\end{tabular}

The sub-criteria used in the Integrity Criteria are explained in Table 3.

Table 3. The Explanation of Integrity Criteria

\begin{tabular}{|c|c|c|c|}
\hline No. & Integrity & Description & Value \\
\hline \multirow[t]{5}{*}{1.} & \multirow{5}{*}{$\begin{array}{l}\text { Be honest and sincere in doing the } \\
\text { task }\end{array}$} & Very Good & 5 \\
\hline & & Good & 4 \\
\hline & & Enough & 3 \\
\hline & & Less & 2 \\
\hline & & Bad & 1 \\
\hline \multirow[t]{5}{*}{2.} & \multirow[t]{5}{*}{ Do not abuse authority } & Very Good & 5 \\
\hline & & Good & 4 \\
\hline & & Enough & 3 \\
\hline & & Less & 2 \\
\hline & & $\mathrm{Bad}$ & 1 \\
\hline \multirow[t]{5}{*}{3.} & \multirow{5}{*}{$\begin{array}{l}\text { Dare to bare the risk of the actions } \\
\text { taken }\end{array}$} & Very Good & 5 \\
\hline & & Good & 4 \\
\hline & & Enough & 3 \\
\hline & & Less & 2 \\
\hline & & $\mathrm{Bad}$ & 1 \\
\hline
\end{tabular}

The sub-criteria used in the Commitment Criteria are explained in Table 4.

Table 4. The Explanation of Commitment Criteria

\begin{tabular}{|l|l|l|l|}
\hline No. & Commitment & Description & Value \\
\hline 1. & \multirow{2}{*}{$\begin{array}{l}\text { Prioritizing the interests of service over } \\
\text { personal interests }\end{array}$} & Very Good & 5 \\
\cline { 3 - 4 } & & Good & 4 \\
\cline { 3 - 4 } & & Enough & 3 \\
\cline { 3 - 4 } & & Less & 2 \\
\cline { 3 - 4 } 2. & \multirow{2}{*}{$\begin{array}{l}\text { Carry out the duties and responsibilities as a } \\
\text { state apparatus }\end{array}$} & Bad & 1 \\
\cline { 3 - 4 } & & Very Good & 5 \\
\cline { 3 - 4 } & & Good & 3 \\
\cline { 3 - 4 } & & Enough & 2 \\
\cline { 3 - 4 } & & Less & 1 \\
\cline { 3 - 4 } & & & \\
\hline
\end{tabular}


The sub-criteria used in the Discipline Criteria are explained in Table 5.

Table 5. The Explanation of Discipline Criteria

\begin{tabular}{|c|c|c|c|}
\hline No. & Discipline & Description & Value \\
\hline \multirow[t]{5}{*}{1.} & \multirow{5}{*}{$\begin{array}{l}\text { Comply with } \\
\text { applicable laws } \\
\text { and/ or official } \\
\text { regulations. }\end{array}$} & Very Good & 5 \\
\hline & & Good & 4 \\
\hline & & Enough & 3 \\
\hline & & Less & 2 \\
\hline & & $\mathrm{Bad}$ & 1 \\
\hline \multirow[t]{5}{*}{2.} & \multirow{5}{*}{$\begin{array}{l}\text { Comply with } \\
\text { working hours. }\end{array}$} & Very Good & 5 \\
\hline & & Good & 4 \\
\hline & & $\begin{array}{l}\text { Enough (Not entering or being late for work and returning early from } \\
\text { working hours provisions without a valid reason for 5-15 working days) }\end{array}$ & 3 \\
\hline & & $\begin{array}{l}\text { Less (Not entering or being late for work and returning early from } \\
\text { working hours without a valid reason for } 16-30 \text { business days) }\end{array}$ & 2 \\
\hline & & $\begin{array}{l}\text { Bad (absent or late for work and return early from working hours without } \\
\text { a valid reason for more than } 31 \text { business days) }\end{array}$ & 1 \\
\hline \multirow[t]{5}{*}{3.} & \multirow{5}{*}{$\begin{array}{l}\text { Able to store } \\
\text { and/or maintain } \\
\text { state-entrusted } \\
\text { goods. }\end{array}$} & Very Good & 5 \\
\hline & & Good & 4 \\
\hline & & Enough & 3 \\
\hline & & Less & 2 \\
\hline & & $\mathrm{Bad}$ & 1 \\
\hline
\end{tabular}

The sub-criteria used in the Cooperation Criteria are explained in Table 6.

Table 6. The Explanation of Cooperation Criteria

\begin{tabular}{|c|c|c|c|}
\hline No. & Cooperation & Description & Value \\
\hline \multirow[t]{5}{*}{1.} & \multirow{5}{*}{$\begin{array}{l}\text { Able to work with colleagues, superiors, } \\
\text { and subordinates. }\end{array}$} & Very Good & 5 \\
\hline & & Good & 4 \\
\hline & & Enough & 3 \\
\hline & & Less & 2 \\
\hline & & $\mathrm{Bad}$ & 1 \\
\hline \multirow[t]{5}{*}{2.} & \multirow{5}{*}{$\begin{array}{l}\text { Able to respect and accept the opinions of } \\
\text { others. }\end{array}$} & Very Good & 5 \\
\hline & & Good & 4 \\
\hline & & Enough & 3 \\
\hline & & Less & 2 \\
\hline & & $\mathrm{Bad}$ & 1 \\
\hline \multirow[t]{5}{*}{3.} & \multirow{5}{*}{$\begin{array}{l}\text { Willing to accept decisions taken legally } \\
\text { that have become decisions. }\end{array}$} & Very Good & 5 \\
\hline & & Good & 4 \\
\hline & & Enough & 3 \\
\hline & & Less & 2 \\
\hline & & $\mathrm{Bad}$ & 1 \\
\hline
\end{tabular}

The sub-criteria used in the Leadership Criteria are explained in Table 7. 
Table 7. The Explanation of Leadership Criteria

\begin{tabular}{|c|c|c|c|}
\hline No. & Leadership & Description & Value \\
\hline \multirow[t]{5}{*}{1.} & \multirow{5}{*}{ Acting decisively and impartially. } & Very Good & 5 \\
\hline & & Good & 4 \\
\hline & & Enough & 3 \\
\hline & & Less & 2 \\
\hline & & $\mathrm{Bad}$ & 1 \\
\hline \multirow[t]{5}{*}{2.} & \multirow{5}{*}{$\begin{array}{l}\text { It can motivate and move the work } \\
\text { team well to achieve performance. }\end{array}$} & Very Good & 5 \\
\hline & & Good & 4 \\
\hline & & Enough & 3 \\
\hline & & Less & 2 \\
\hline & & $\mathrm{Bad}$ & 1 \\
\hline \multirow[t]{5}{*}{3.} & \multirow{5}{*}{$\begin{array}{l}\text { Able to take decisions quickly and } \\
\text { accurately. }\end{array}$} & Very Good & 5 \\
\hline & & Good & 4 \\
\hline & & Enough & 3 \\
\hline & & Less & 2 \\
\hline & & $\mathrm{Bad}$ & 1 \\
\hline
\end{tabular}

The Work Realization Criteria used are explained in Table 8.

Table 8. The Explanation of Work Realization Criteria

\begin{tabular}{|l|l|l|}
\hline No. & Work Realization & Value \\
\hline 1. & Realized $81-100 \%$ & 5 \\
\hline 2. & Realized $61-80 \%$ & 4 \\
\hline 3. & Realized $41-60 \%$ & 3 \\
\hline 4. & Realized $21-40 \%$ & 2 \\
\hline 5. & Realized $0-20 \%$ & 1 \\
\hline
\end{tabular}




\section{ALTERNATIVES DATA}

Alternatives Data used are described in Table 9.

Table 9. Alternatives Data

\begin{tabular}{|c|c|c|c|c|c|c|c|}
\hline $\mathrm{C}$ & Sub-Criteria & A1 & $\mathrm{A} 2$ & A3 & A4 & A5 & $\begin{array}{l}\text { Work } \\
\text { Standard }\end{array}$ \\
\hline \multirow[t]{2}{*}{$\mathrm{C} 1$} & $\begin{array}{l}\text { Complete the task as possible with a polite and satisfying } \\
\text { attitude for internal and external services }\end{array}$ & 4 & 4 & 3 & 4 & 3 & 3 \\
\hline & Make efforts to improve services quickly & 4 & 3 & 3 & 4 & 3 & 3 \\
\hline \multirow{3}{*}{$\mathrm{C} 2$} & Be honest and sincere in doing the task & 4 & 4 & 3 & 4 & 3 & 3 \\
\hline & Do not abuse authority & 3 & 4 & 3 & 4 & 3 & 3 \\
\hline & Dare to bare the risk of the actions taken & 4 & 3 & 2 & 4 & 2 & 3 \\
\hline \multirow[b]{2}{*}{$\mathrm{C} 3$} & Prioritizing the interests of service over personal interests & 4 & 3 & 2 & 3 & 2 & 3 \\
\hline & $\begin{array}{l}\text { Carry out the duties and responsibilities as a state } \\
\text { apparatus }\end{array}$ & 4 & 3 & 3 & 4 & 3 & 3 \\
\hline \multirow{3}{*}{$\mathrm{C} 4$} & Comply with applicable laws and/ or official regulations. & 4 & 4 & 4 & 4 & 3 & 3 \\
\hline & Comply with working hours. & 3 & 4 & 3 & 3 & 2 & 3 \\
\hline & Able to store and/or maintain state-entrusted goods. & 2 & 4 & 2 & 4 & 2 & 3 \\
\hline \multirow{3}{*}{$\mathrm{C} 5$} & Able to work with colleagues, superiors, and subordinates. & 3 & 3 & 3 & 4 & 3 & 3 \\
\hline & Able to respect and accept the opinions of others. & 3 & 4 & 4 & 4 & 3 & 3 \\
\hline & $\begin{array}{l}\text { Willing to accept decisions taken legally that have become } \\
\text { decisions. }\end{array}$ & 4 & 4 & 4 & 4 & 3 & 3 \\
\hline \multirow{3}{*}{ C6 } & Acting decisively and impartially. & 4 & 3 & 3 & 4 & 3 & 3 \\
\hline & $\begin{array}{l}\text { Can motivate and move the work team well to achieve } \\
\text { performance }\end{array}$ & 4 & 3 & 3 & 3 & 2 & 3 \\
\hline & Able to make decisions quickly and accurately. & 3 & 3 & 2 & 3 & 2 & 3 \\
\hline $\mathrm{C} 7$ & - & 4 & 3 & 2 & 4 & 1 & 2 \\
\hline
\end{tabular}

The work standards are the value of work standards that must be achieved by employees which later the value of performance standards is used as a standard for determining employees who get rewards and punishment. Then, alternative values obtained from the average value of each criterion were calculated. The alternative values used are described in Table 10.

Table 10. Alternatives Value

\begin{tabular}{|l|l|l|l|l|l|l|}
\hline Criteria & A1 & A2 & A3 & A4 & A5 & Work Standard \\
\hline C1 & 4 & 3,5 & 3 & 4 & 3 & 3 \\
\hline C2 & 3,67 & 3,67 & 2,67 & 4 & 2,67 & 3 \\
\hline C3 & 4 & 3 & 2,5 & 3,5 & 2,5 & 3 \\
\hline C4 & 3 & 4 & 3 & 3,67 & 2,33 & 3 \\
\hline C5 & 4 & 3,67 & 3,67 & 4 & 3 & 3 \\
\hline C6 & 3,67 & 3 & 2,67 & 3,33 & 2,33 & 3 \\
\hline C7 & 4 & 3 & 2 & 4 & 1 & 2 \\
\hline
\end{tabular}

The Calculation of the WASPAS method:

1. Create a Decision Matrix (Xij) 


$$
\mathrm{Xij}=\left[\begin{array}{cccllcl}
4 & 3,667 & 4 & 3 & 4 & 3,667 & 4 \\
3.5 & 3,667 & 3 & 4 & 3,667 & 3 & 3 \\
3 & 2,667 & 2,5 & 3 & 3,667 & 2,667 & 2 \\
4 & 4 & 3,5 & 3,667 & 4 & 3,333 & 4 \\
3 & 2,667 & 2,5 & 2,333 & 3 & 2,333 & 2 \\
3 & 3 & 2 & 3 & 3 & 3 & 2
\end{array}\right]
$$

2. Determine the Optimal Performance Value for Each Criterion $\left(\mathrm{X}_{\mathrm{o}}\right)$ Table 11. Optimal Performance Value for Each Criterion $\mathrm{T}$

\begin{tabular}{|l|l|l|l|l|l|l|l|}
\hline Alternatives & C1 & C2 & C3 & C4 & C5 & C6 & C7 \\
\hline A1 & 4 & 3,67 & 4 & 3 & 4 & 3,67 & 4 \\
\hline A2 & 3,5 & 3,67 & 3 & 4 & 3,67 & 3 & 3 \\
\hline A3 & 3 & 2,67 & 2,5 & 3 & 3,67 & 2,67 & 2 \\
\hline A4 & 4 & 4 & 3,5 & 3,67 & 4 & 3,33 & 4 \\
\hline A5 & 3 & 2,67 & 2,5 & 2,33 & 3 & 2,33 & 1 \\
\hline Work Standard & 3 & 3 & 3 & 3 & 3 & 3 & 2 \\
\hline Xo Max & 4 & 4 & 4 & 4 & 4 & 3,67 & 4 \\
\hline
\end{tabular}

3. Create a Normalized Decision Matrix (Xij)

$$
\mathrm{R}_{\mathrm{ij}}=\left[\begin{array}{ccccccl}
1 & 0,917 & 1 & 0,75 & 1 & 1 & 1 \\
0,875 & 0,917 & 0,75 & 1 & 0,917 & 0,818 & 0,75 \\
0,75 & 0,667 & 0,625 & 0,75 & 0,917 & 0,727 & 0,5 \\
1 & 1 & 0,875 & 0,917 & 1 & 0,908 & 1 \\
0,75 & 0,667 & 0,625 & 0,583 & 0,75 & 0,635 & 0,25 \\
0,75 & 0,75 & 0,75 & 0,75 & 0,75 & 0,818 & 0,5
\end{array}\right]
$$

4. Calculate Total Relative Importance by Weighted Sum Model (Qi $\left.{ }^{1}\right)$ Table 12. Total Relative Importance by Weighted Sum Model

\begin{tabular}{|l|l|}
\hline Alternative & $\mathrm{Qi}^{1}$ \\
\hline A1 & 0,96585 \\
\hline A2 & 0,84393 \\
\hline A3 & 0,67984 \\
\hline A4 & 0,96623 \\
\hline A5 & 0,56641 \\
\hline Work Standard & 0,69431 \\
\hline
\end{tabular}

5. Calculate Total Relative Importance by Weighted Product Model $\left(\mathrm{Qi}^{2}\right)$

Table 13. Total Relative Importance by Weighted Product Model

\begin{tabular}{|l|l|}
\hline Alternative & $\mathrm{Qi}^{2}$ \\
\hline A1 & 6,96283 \\
\hline A2 & 6,82908 \\
\hline A3 & 6,61387 \\
\hline A4 & 6,96451 \\
\hline A5 & 6,41496 \\
\hline Work Standard & 6,63819 \\
\hline
\end{tabular}

6. Calculate Total Relative Significant (Qi) 
Table 14. Total Relative Significant (Qi)

\begin{tabular}{|l|l|l|l|}
\hline Alternative & $\mathrm{Qi}^{1}$ & $\mathrm{Qi}^{2}$ & $0,5 \mathrm{Qi}^{1}+0,5 \mathrm{Qi}^{2}$ \\
\hline A1 & 0,96585 & 6,96283 & 3,964339 \\
\hline A2 & 0,84393 & 6,82908 & 3,836504 \\
\hline A3 & 0,67984 & 6,61387 & 3,646859 \\
\hline A4 & 0,96623 & 6,96451 & 3,965371 \\
\hline A5 & 0,56641 & 6,41496 & 3,490686 \\
\hline Work Standard & 0,69431 & 6,63819 & 3,666250 \\
\hline
\end{tabular}

7. Alternative Rank

Table 15. Alternative Rank

\begin{tabular}{|c|c|c|l|}
\hline Alternative & Qi & Ranking & \multicolumn{1}{|c|}{ Results } \\
\hline A1 & 3,964339 & 2 & Reached \\
\hline A2 & 3,836504 & 3 & Reached \\
\hline A3 & 3,646859 & 4 & Punishment \\
\hline A4 & 3,965371 & 1 & Reward \\
\hline A5 & 3,490686 & 5 & Punishment \\
\hline Work Standard & \multicolumn{3}{|c}{ Qi = 3,666250 } \\
\hline
\end{tabular}

\section{CONCLUSION}

The implementation of the WASPAS method in a decision support system can provide recommendations to help decision-makers evaluate employee performance to determine employee who gets reward and punishments efficiently and more objectively. Based on ranking results obtained that Alternative 4 with a value of Q4 $=3.965371$ is the best alternative with the largest Qi value that will get a reward, while Alternatives 3 and 5 with a value of Q3 = $3.646859, \mathrm{Q} 5=3.490686$ is an alternative with a Qi value below performance standards that will get punishment.

\section{REFERENCES}

[1] S. Chakraborty, O. Bhattacharyya, E. K. Zavadskas, and J. Antucheviciene, "Application of WASPAS method as an optimization tool in nontraditional machining processes," Inf. Technol. Control, vol. 44, no. 1, pp. 77-88, 2015.

[2] K. A. Alam, R. Ahmed, F. S. Butt, S. G. Kim, and K. M. Ko, "An Uncertainty-aware Integrated Fuzzy AHP-WASPAS Model to Evaluate Public Cloud Computing Services," Procedia Comput. Sci., vol. 130, pp. 504-509, 2018.

[3] S. Chakraborty, E. K. Zavadskas, and J. Antucheviciene, "Applications of WASPAS method as a multi-criteria decision-making tool," Econ. Comput. Econ. Cybern. Stud. Res., vol. 49, no. 1, pp. 1-17, 2015.
[4] S. Hashemkhani Zolfani, M. H. Aghdaie, A. Derakhti, E. K. Zavadskas, and M. H. Morshed Varzandeh, "Decision making on business issues with foresight perspective; An application of new hybrid MCDM model in shopping mall locating," Expert Syst. Appl., vol. 40, no. 17, pp. 7111-7121, 2013.

[5] D. Arnott and G. Pervan, "Eight key issues for the decision support systems discipline," Decis. Support Syst., vol. 44, no. 3, pp. 657-672, 2008.

[6] R. Accorsi, R. Manzini, and F. Maranesi, “A decision-support system for the design and management of warehousing systems," Comput. Ind., 2014.

[7] P. D. D. Dominic, I. A. Aziz, and K. N. Goh, "A decision support system for performance appraisal," Int. Conf. Inf. Technol. New Gener. ITNG 2008, pp. 899-903, 2008.

[8] S. B. M. Marume, P. D. Ndudzo, and A. S. Chikasha, "Decision-Making," Int. J. Bus. Manag. Invent., vol. 5, no. 8, pp. 36-44, 2016.

[9] M. R. Yavarzadeh and A. Rabi, "the Impact of Reward System on Human Resource Productivity in Chain Stores," Int. J. Econ. Commer. Manag., vol. III, no. 11, pp. 528-545, 2015.

[10] M. Salah, "The Influence of Rewards on Employees Performance," Br. J. Econ. Manag. Trade, vol. 13, no. 4, pp. 1-25, 2016. 
[12] H. Prajapati, R. Kant, and R. Shankar, "Prioritizing the solutions of reverse logistics implementation to mitigate its barriers: A hybrid modified SWARA and WASPAS approach," J. Clean. Prod., vol. 240, p. 118219, 2019. 